\title{
LOCAL BURNUP CHARACTERISTICS OF PWR SPENT NUCLEAR FUELS DISCHARGED FROM YEONGGWANG-2 NUCLEAR POWER PLANT
}

\author{
YEONG-KEONG HA*, JUNGSUCK KIM, YOUNG SHIN JEON, SUN HO HAN, HANG SEOK SEO and KYUSEOK SONG \\ Korea Atomic Energy Research Institute \\ 1045 Daedeokdaero, Yuseong-gu, Daejeon, 305-353, Korea \\ "Corresponding author. E-mail : nykha@kaeri.re.kr
}

Received March 31, 2009

Accepted for Publication November 9, 2009

\begin{abstract}
Spent $\mathrm{UO}_{2}$ nuclear fuel discharged from a nuclear power plant (NPP) contains fission products, $\mathrm{U}, \mathrm{Pu}$, and other actinides. Due to neutron capture by ${ }^{238} \mathrm{U}$ in the rim region and a temperature gradient between the center and the rim of a fuel pellet, a considerable increase in the concentration of fission products, $\mathrm{Pu}$, and other actinides are expected in the pellet periphery of high burnup fuel. The characterization of the radial profiles of the various isotopic concentrations is our main concern. For an analysis, spent nuclear fuels originating from the Yeonggwang-2 pressurized water reactor (PWR) were chosen as the test specimens. In this work, the distributions of some actinide isotopes were measured from center to rim of the spent fuel specimens by a radiation shielded laser ablation inductively coupled plasma mass spectrometer (LA-ICP-MS) system. Sampling was performed along the diameter of the specimen by reducing the sampling intervals from $500 \mu \mathrm{m}$ in the center to $100 \mu \mathrm{m}$ in the pellet periphery region. It was observed that the isotopic concentration ratios for minor actinides in the center of the specimen remain almost constant and increase near the pellet periphery due to the rim effect apart from the ${ }^{236} \mathrm{U}$ to ${ }^{235} \mathrm{U}$ ratio, which remains approximately constant. In addition, the distributions of local burnup were derived from the measured isotope ratios by applying the relationship between burnup and isotopic ratio for plutonium and minor actinides calculated by the ORIGEN2 code.
\end{abstract}

KEYWORDS : Spent Fuel, Local Burnup, Laser Ablation, ICP-MS, Uranium, Plutonium, Minor Actinide

\section{INTRODUCTION}

Nuclear power has played an important role in meeting the energy demand which has continuously increased along with the economic growth in Korea. Now, it accounts for more than $40 \%$ of the electricity supply in Korea [1]. For economic reasons, the average discharge burnup of fuel assembly has recently reached $55 \mathrm{GWd} / \mathrm{tU}$ by extended fuel cycle and higher ${ }^{235} \mathrm{U}$-enrichment. This high burnup nuclear fuel requires an experimental database to support the fuel integrity, safety analysis, and shielding design. At such high burnup, the composition of a nuclear fuel changes in a non-homogeneous manner throughout the radius, and a porous outer ring with a thickness up to $\sim 200 \mu \mathrm{m}$ is formed [2,3]. Among these non-homogeneous properties, the compositional change along with the diameter of the fuel pellet is our main concern.

In general, the analysis of fission products and actinides is carried out after dissolution of a fuel pellet $[4,5]$. However, the chemical analysis of spent fuel based on the dissolution method cannot provide information about the local burnup variation with radius, though it provides an accurate estimation of fissile material depletion in nuclear fuel [6]. Since the introduction of the laser ablation technique, laser sampling was used in conjunction with inductively coupled plasma mass spectrometer (ICP-MS), which allows a route for studying the distribution of elements in a solid sample by probing the sample with a laser beam $[7,8]$.

A study of the local burnup characteristics in spent fuel was difficult due to the lack of instrumentation, as well as the difficulties in sample handling. Most recently, a radiation shielded laser ablation inductively coupled plasma mass spectrometer (LA-ICP-MS) was built for a spatial analysis of highly radioactive solid materials [9]. In this work, the radial distributions of isotopes were measured by this shielded LA-ICP-MS system and the local burnups of spent fuel specimens were predicted from the measured isotopic concentration ratios by applying the correlations derived by ORIGEN2 code. 


\section{EXPERIMENTAL}

\subsection{Instruments}

ICP-MS has been used as a powerful analytical tool for the determination of isotopic concentration ratios at the trace level due to its sensitivity and accuracy. For a direct analysis of a solid sample without pretreatment, laser ablation is a very efficient sampling technique [10] involving evaporation of the sample material using a focused laser beam in an inert gas (e.g., Ar) under normal pressure. By combining the laser ablation technique with the ICP-MS, a spatial analysis of a heterogeneous solid sample was achieved. Most LA-ICP-MS systems use a commercial LA system (e.g., CETEK, Merchantek), which is inadequate for a highly radioactive sample analysis. For this reason, a shielded LA system was built in order to avoid a dose to the operator. The LA system consisted of a Q-switched Nd:YAG laser, an image analyzer, a XYZ translator with motion controller, an ablation chamber, and various optics. Details of this system were described in our previous paper [9]. This system was connected to an ICP-MS (Element, Finnigan) via a PVC tube with an argon flow of $1 \mathrm{l} / \mathrm{min}$. The ablated particles were transported to the plasma of the ICP-MS; the operating conditions of the ICP-MS system are summarized in Table 1.

\subsection{Specimen Preparation}

Spent fuels originating from the Yeonggwang-2 nuclear power plant (NPP) were chosen as the test specimens. For comparison, two specimens were taken from fuel rod P14P17 at axial positions of $180 \mathrm{~mm}$ (P14P17-1) and $3340 \mathrm{~mm}$ (P14P17-2) from the bottom of the fuel rod, and a third specimen was taken from a different fuel rod (P11Q01) at the axial position of $1595 \mathrm{~mm}$ from the bottom of the fuel rod for the measurement of isotopic distribution. The rod average burnups (corresponding to power plant estimated burnups) were 48.7 and $55.8 \mathrm{GWd} / \mathrm{tU}$ for P14P17 and $\mathrm{P} 11 \mathrm{Q} 01$, respectively. In order to estimate the axial burnup of the fuel rod, gamma scanning measurements at energies corresponding to ${ }^{137} \mathrm{Cs}$ were performed and then the specimen burnups were calculated from the rod average burnups normalized by the measured distribution of the ${ }^{137} \mathrm{Cs}$ gamma intensities along the axial length of the fuel rod. The estimated specimen burnups were $37.1,44.3$ and $60.9 \mathrm{GWd} / \mathrm{tU}$ for P14P17-1, P14P17-2 and P11Q01, respectively. Axial slices of $3 \mathrm{~mm}$ height were cut from the spent fuel rods along the cross-section of a fuel pellet including both fuel and cladding. The specimens were taken from the diameters of the axial slices with $1 \mathrm{~mm}$ in

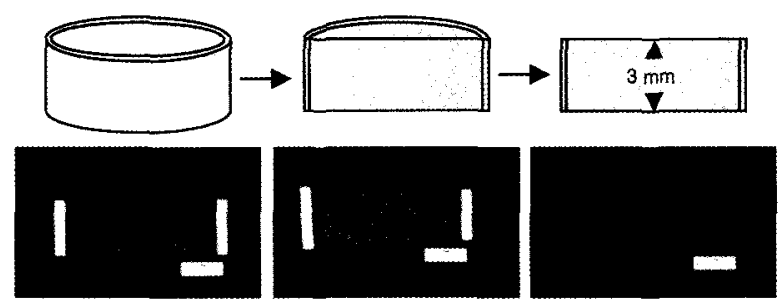

(a)

(b)

(c)

Fig. 1. Prepared Spent Fuel Specimens Originating from the Yeonggwang-2 NPP in Korea. (Time after Discharge to Measurement: 3 Years). (a) P14P17-1, (b) P14P17-2, (c) P11Q01

Table 1. Operating Conditions of the ICP-MS System

\begin{tabular}{|c|c|c|}
\hline & Parameter & Conditions \\
\hline ICP-MS & $\begin{array}{l}\text { RF Power } \\
\text { Cooling gas flow } \\
\text { Auxiliary gas flow } \\
\text { Sampling gas flow } \\
\text { Sample cone } \\
\text { Skimmer cone } \\
\text { Mass resolution } \\
\text { Quadrupole working pressure } \\
\text { Detection mode }\end{array}$ & $\begin{array}{l}1300 \mathrm{~W} \\
13 \mathrm{l} / \mathrm{min} \\
0.7 \mathrm{l} / \mathrm{min} \\
1.0 \mathrm{l} / \mathrm{min} \\
\text { Nickel with a } 1.1 \mathrm{~mm} \text { orifice } \\
\text { Nickel with a } 0.8 \mathrm{~mm} \text { orifice } \\
300 \mathrm{~m} / \Delta \mathrm{m} \\
10^{-7} \mathrm{mbar} \\
\text { counting }\end{array}$ \\
\hline Laser Ablation & $\begin{array}{l}\text { Laser source } \\
\text { Laser power } \\
\text { Repetition rate } \\
\text { Sampling time } \\
\text { Beam profile }\end{array}$ & $\begin{array}{l}\text { Nd:YAG } 266 \mathrm{~nm} \\
48 \%(4 \mathrm{~mJ} \text { at } 100 \%) \\
10 \mathrm{~Hz} \\
2 \mathrm{sec} \\
\text { Tem }_{00} \text { mode }\end{array}$ \\
\hline
\end{tabular}


thickness. The specimens were embedded in epoxy resin and then polished well in the post-irradiation examination (PIE) facility in KAERI. The prepared specimens are shown in Fig. 1. The time after discharge to measurement was ca. 3 years for all specimens.

Another two specimens from the P14P17-1 and P14P172 pellets were prepared for the measurements of specimen average burnups by the chemical dissolution method. In the case of P11Q01, two neighboring pellets (P11Q01-2, P11Q01-5) of the P11Q01 specimen were taken for the burnup analysis by the dissolution method.

\subsection{Specimen Transportation}

A radiation shielded specimen cask was fabricated to transport a spent fuel specimen from the hot cell to the shielded LA glove box. The cask was shielded by lead with a wall thickness of $70 \mathrm{~mm}$ between two stainless steel walls of $10 \mathrm{~mm}$ thickness so that the maximum dose received by the operator is lower than $25 \mu \mathrm{Sv} / \mathrm{h}$, as per a shielded glove box [9]. The cask was fitted securely with both cask adaptors on the hot cell wall and the shielded glove box. The cask door can only be opened when the cask is joined securely to the cask adaptor. A safety pin on the cask helps to keep the door locked during transportation. Fig. 2 shows the cask fitted with a cask adaptor on the hot cell wall and a specimen basket of the cask in the hot cell to bring a spent fuel specimen in and out.

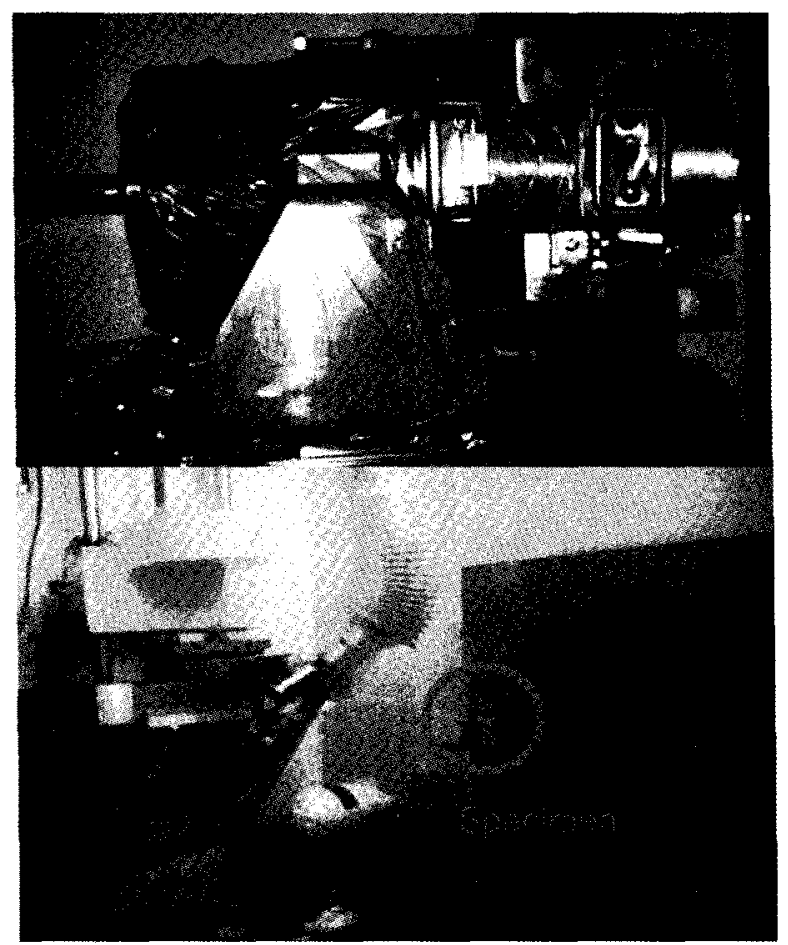

Fig. 2. Specimen Cask Fitted with the Adaptor on a Hot Cell Wall (Upper) and a Specimen Basket of Cask Inside a Hot Cell (Lower)

\section{RESULTS AND DISCUSSIONS}

\subsection{Burnup Determination by Nd Method}

For the measurement of specimen burnups, two pieces (P14P17-1, P14P17-2) of spent fuel with 37.1 and 44.3 $\mathrm{GWd} / \mathrm{tU}$ estimated specimen burnup, and two pieces (P11Q01-2, P11Q01-5) of spent fuel with $60.9 \mathrm{GWd} / \mathrm{tU}$ estimated specimen burnup were analyzed by the chemical dissolution method. The measurement processes are as follows. Dissolution of the samples was carried out using both $8 \mathrm{M} \mathrm{HNO}_{3}$ and $16 \mathrm{M} \mathrm{HNO}_{3}$ at $90^{\circ} \mathrm{C}$ for 8 hours with each solvent. After dissolution, the solutions were diluted by $8 \mathrm{M} \mathrm{HNO}_{3}$. The spent fuel (SF) samples with and without a spike $\left({ }^{233} \mathrm{U},{ }^{242} \mathrm{Pu},{ }^{150} \mathrm{Nd}\right)$ addition were prepared and then the $\mathrm{U}, \mathrm{Pu}$ and $\mathrm{Nd}$ were separated by ion exchange chromatography (Biorad AG $1 \times 4$ and $1 \times 8$ ). The details of the separation process are described elsewhere [6]. Each fraction of $\mathrm{U}, \mathrm{Pu}$ and $\mathrm{Nd}$ was collected from the sample solution and the isotopic compositions were measured by mass spectrometry. The isotope compositions were measured using a thermal ionization mass spectrometer (TIMS). The details of the burnup measurement processes are described in Fig. 3.

The cross-section averaged burnups of the SF specimens were calculated based on the Nd-148 method (ASTM, E321-96) [11] by the use of the following equation.

$$
\text { Atom } \% \text { fission }\left(F_{T}\right)=\frac{N / Y}{N / Y+N(U)+N(P u)} \times 100
$$

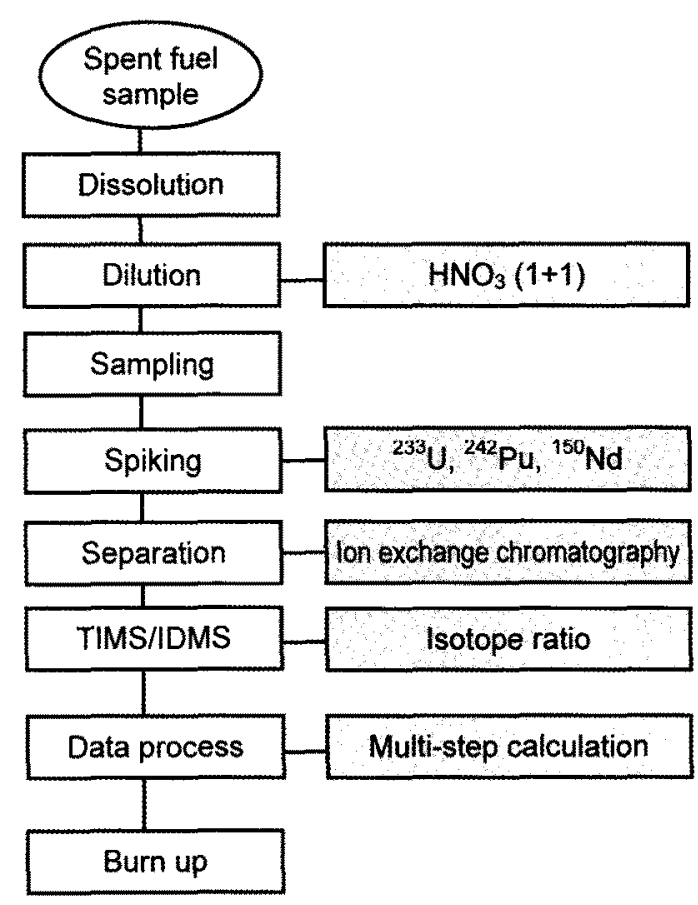

Fig. 3. Procedures for a Burnup Determination 
Table 2. Estimated Effective Fission Yields for Nd Isotopes in the PWR Fuel Samples

\begin{tabular}{c|c|c|c|c}
\hline \multirow{2}{*}{ Nd Isotope } & \multicolumn{4}{|c}{ Effective fission yield (\%) } \\
\cline { 2 - 5 } & P14P17-1 & P14P17-2 & P11Q01-2 & P11Q01-5 \\
\hline 143 & 5.6719 & 5.5951 & 5.4534 & 5.4726 \\
\hline 144 & 5.1870 & 5.1046 & 4.9543 & 4.9748 \\
\hline 145 & 3.7657 & 3.7216 & 3.6413 & 3.6523 \\
\hline 146 & 2.9073 & 2.8848 & 2.8449 & 2.8504 \\
\hline 148 & 1.6787 & 1.6820 & 1.6902 & 1.6891 \\
\hline 150 & 0.7217 & 0.7420 & 0.7814 & 0.7761 \\
\hline
\end{tabular}

Table 3. Burnup Determined by the Nd-isotope Methods

\begin{tabular}{c|c|c|c}
\hline \multirow{2}{*}{ Sample specimen } & \multicolumn{3}{|c}{ Burnup (GWd/tU) } \\
\cline { 2 - 4 } & Nd-148 & Nd-(145+146) & Nd-total $^{*}$ \\
\hline P14P17-1 & $33.33 \pm 1.04$ & $34.16 \pm 1.07$ & $33.52 \pm 1.05$ \\
\hline P14P17-2 & $40.97 \pm 1.28$ & $41.96 \pm 1.31$ & $41.37 \pm 1.29$ \\
\hline P11Q01-2 & $58.21 \pm 1.82$ & $60.30 \pm 1.88$ & $58.65 \pm 1.83$ \\
\hline P11Q01-5 & $57.00 \pm 1.78$ & $58.81 \pm 1.84$ & $57.82 \pm 1.81$ \\
\hline
\end{tabular}

${ }^{*} 143+144+145+146+148+150$

where $F_{T}$ is the burnup from fission of all fissionable isotopes (total burnup), $\mathrm{N}$ is the number of atoms of the monitor $\mathrm{Nd}$ isotope in the spent fuel solution, $\mathrm{Y}$ is the effective fission yield of the monitor $\mathrm{Nd}$ isotope from the fissile elements, and $\mathrm{N}(\mathrm{U})$ and $\mathrm{N}(\mathrm{Pu})$ are the number of uranium and plutonium atoms in the fuel solution, respectively. The $\mathrm{Y}$ value is derived from an average weighted fission yield $[12,13]$.

The effective fission yields and burnup determined by the Nd method are listed in Table 2 and Table 3 , respectively. Both samples from rod P14P17 revealed lower burnups than the average burnup of $48.7 \mathrm{GWd} / \mathrm{tU}$ calculated from ORIGEN2, since the specimens were picked from near the top and the bottom of the fuel rod. Both samples of P11Q01 revealed higher burnups than the rod average burnup $(55.8 \mathrm{GWd} / \mathrm{tU})$ calculated from ORIGEN2, since both specimens were taken from near the center of the fuel rods. All of them revealed lower burnups, in the range of 3.3 to $3.9 \mathrm{GWd} / \mathrm{tU}$, than the estimated ones. The burnups obtained by the Nd-148 method agreed well with those obtained by the $\mathrm{Nd}-(145+146)$ and Nd-total isotope methods within $3.6 \%$ relative deviation.

\subsection{Distribution of U, Pu in the Spent Fuel Specimens}

The prepared sample specimens were transferred into the ablation chamber in the shielded glove box for the isotope ratio measurements. Sampling was carried out by a Q-switched Nd:YAG laser at $266 \mathrm{~nm}$. The laser was operated at $48 \%$ laser power $(4 \mathrm{~mJ}$ at $100 \%), 10 \mathrm{~Hz}$ repetition rate and $2 \mathrm{~s}$ sampling time. The ablated particles were carried to the plasma of the ICP-MS system through a PVC tube by Ar carrier gas. The ICP-MS system was optimized at the maximum ion intensity for ${ }^{238} \mathrm{U}$. Operating conditions of the LA-ICP-MS system are summarized in Table 1.

Increased burnup causes compositional variations along the radius, and results in the 'rim zone' at a pellet periphery [3]. To observe the rim effect, sampling was carried out with varying intervals from $500 \mu \mathrm{m}$ intervals around the pellet center, 200 to $300 \mu \mathrm{m}$ intervals in the middle, and finally with $100 \mu \mathrm{m}$ intervals in the pellet periphery. Among the actinides, the isotopes of ${ }^{236} \mathrm{U},{ }^{239} \mathrm{Pu}$, ${ }^{240} \mathrm{Pu}$ and ${ }^{241} \mathrm{Pu}$ in the spent fuel were our main concern. The isotope ratios of $\mathrm{U}$ and $\mathrm{Pu}$ from the center to pellet outer surface of the SF specimen were determined without quantitative analysis of isotopic concentrations due to a lack of reference material [14]. The peak areas of each isotope as fractions of the peak area at mass $235\left({ }^{235} \mathrm{U}\right)$ were used to determine the radial distributions of the $U$ and $\mathrm{Pu}$ isotopes.

Fig. 4 shows the isotope ratios of ${ }^{236} \mathrm{U}$ and ${ }^{239,240,241} \mathrm{Pu}$ to ${ }^{235} \mathrm{U}$ as a function of the distance to the pellet rim. Since the fuel pellet diameter is ca. $8 \mathrm{~mm}$, around $4000 \mu \mathrm{m}$ in $x$-axis is the pellet center and $0 \mu \mathrm{m}$ is the pellet periphery. As can be observed, the ${ }^{236} \mathrm{U}$ (formed by neutron capture of ${ }^{235} \mathrm{U}$ ) to ${ }^{235} \mathrm{U}$ ratio was almost constant, while the Pu isotopes to ${ }^{235} \mathrm{U}$ ratios were increased significantly at the pellet 

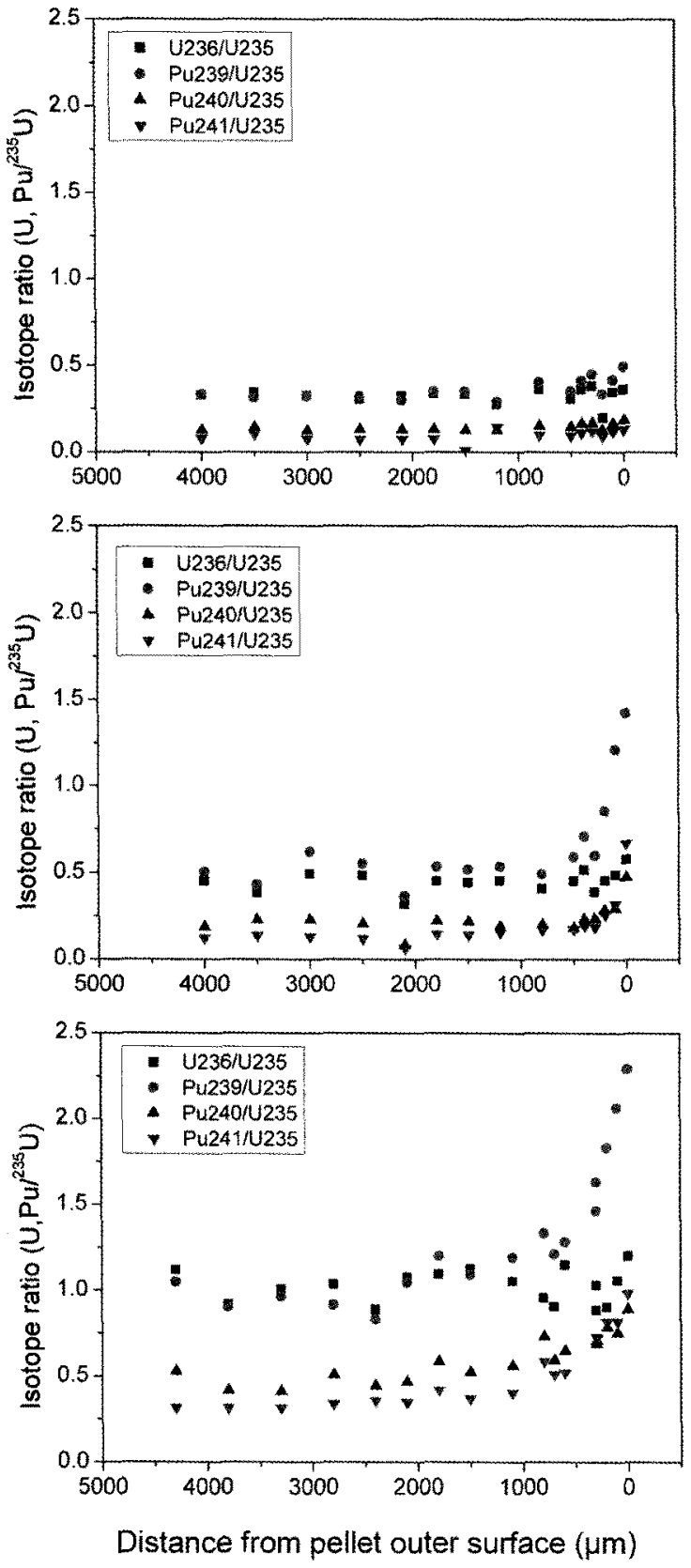

Fig. 4. Distributions of U, Pu Isotopes across the Radius of Spent Nuclear Fuels Discharged from the Yeonggwang-2 PWR Reactor: (Top) $33.3 \mathrm{GWd} / \mathrm{tU}$, (Middle) $41.0 \mathrm{GWd} / \mathrm{tU}$, (Bottom) $57.6 \mathrm{GWd} / \mathrm{tU}$

periphery (so called rim effect). The higher $\mathrm{Pu}$ isotope ratios are known to be a result of successive neutron capture reactions by ${ }^{238} \mathrm{U}$ at the pellet periphery. The mass of 241 corresponds both to ${ }^{241} \mathrm{Pu}$ and its beta decay product, ${ }^{24 !} \mathrm{Am}$.

Since a spent fuel reference material does not exist, the reliability of the measured data was determined by the reproducibility of the isotope ratios measured at the same radial position. Fig 5 shows the reproducibility of

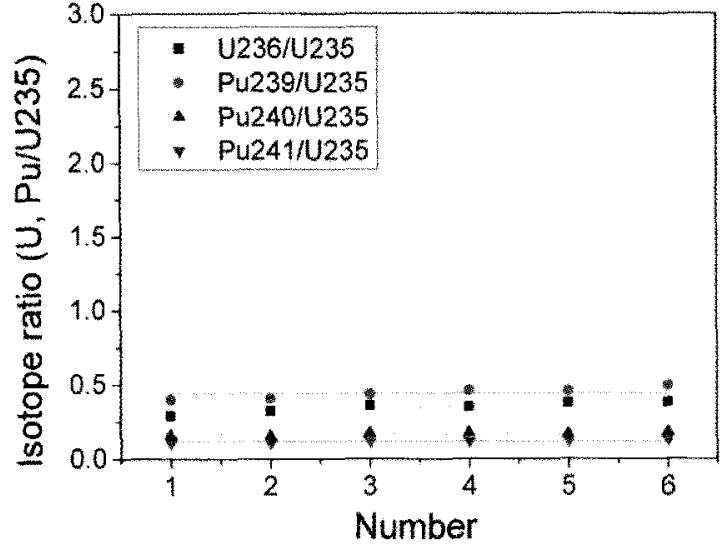

(a) P14P17-1

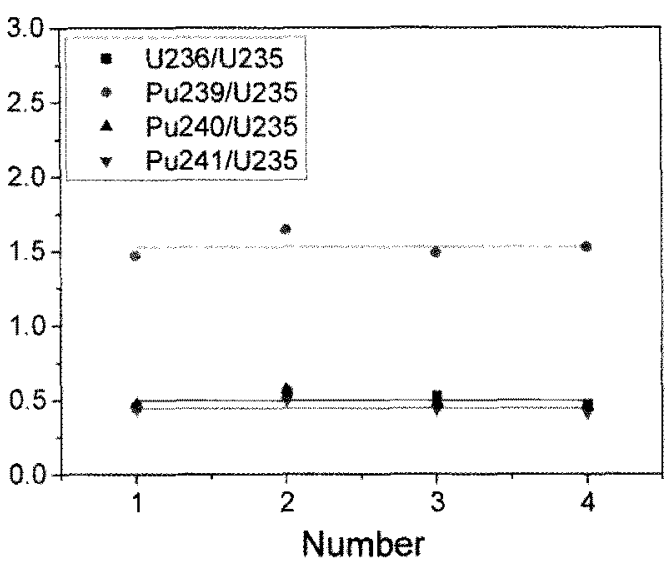

(b) P14P17-2

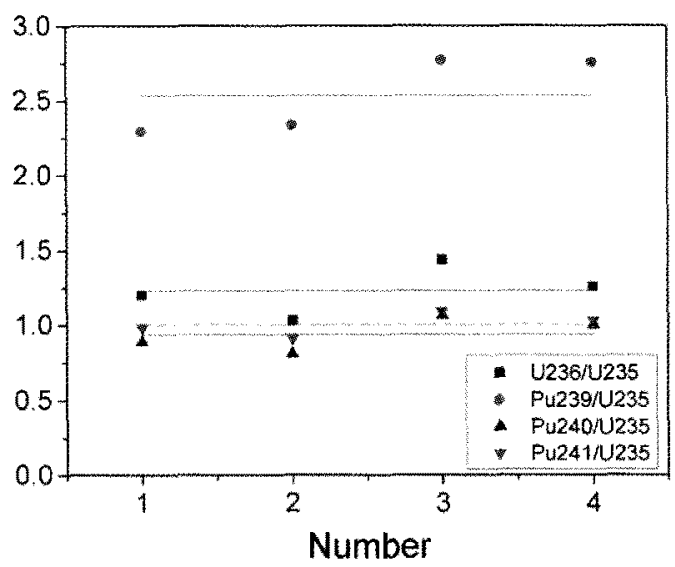

(c) P11Q01

Fig. 5. Reproducibility of Isotope Ratios of U, Pu Measured at the Same Position in Spent Fuel Specimens with Different Burnups: (a) $33.3 \mathrm{GWd} / \mathrm{tU}$, (b) $41.0 \mathrm{GWd} / \mathrm{tU}$, (c) $57.6 \mathrm{GWd} / \mathrm{tU}$

the isotope ratio determined by repeating measurements at the same position, and the relative standard deviations (RSDs) are listed in Table 4. The measured RSD values were in the range between 7 to $10 \%$ for the lowest burnup and $8 \sim 14 \%$ for the highest burnup. 
Table 4. Relative Standard Deviations (RSD, \%) of the Isotope Ratios of U, Pu to ${ }^{235} \mathrm{U}$ Measured at the Same Position in Spent Nuclear Fuels with Different Burnups

\begin{tabular}{c|c|c|c}
\hline \multirow{2}{*}{ isotope } & \multicolumn{2}{|c}{ RSD (\%) } & $57.6 \mathrm{GWd} / \mathrm{tU}$ \\
\cline { 2 - 4 } & $33.3 \mathrm{GWd} / \mathrm{tU}$ & $41.0 \mathrm{GWd} / \mathrm{tU}$ & 13.53 \\
\hline${ }^{236} \mathrm{U}$ & 9.85 & 9.52 & 10.20 \\
\hline${ }^{239} \mathrm{Pu}$ & 8.11 & 5.12 & 12.22 \\
\hline${ }^{240} \mathrm{Pu}$ & 6.62 & 10.73 & 7.68 \\
\hline${ }^{241} \mathrm{Pu}$ & 8.53 & 7.91 & \\
\hline
\end{tabular}
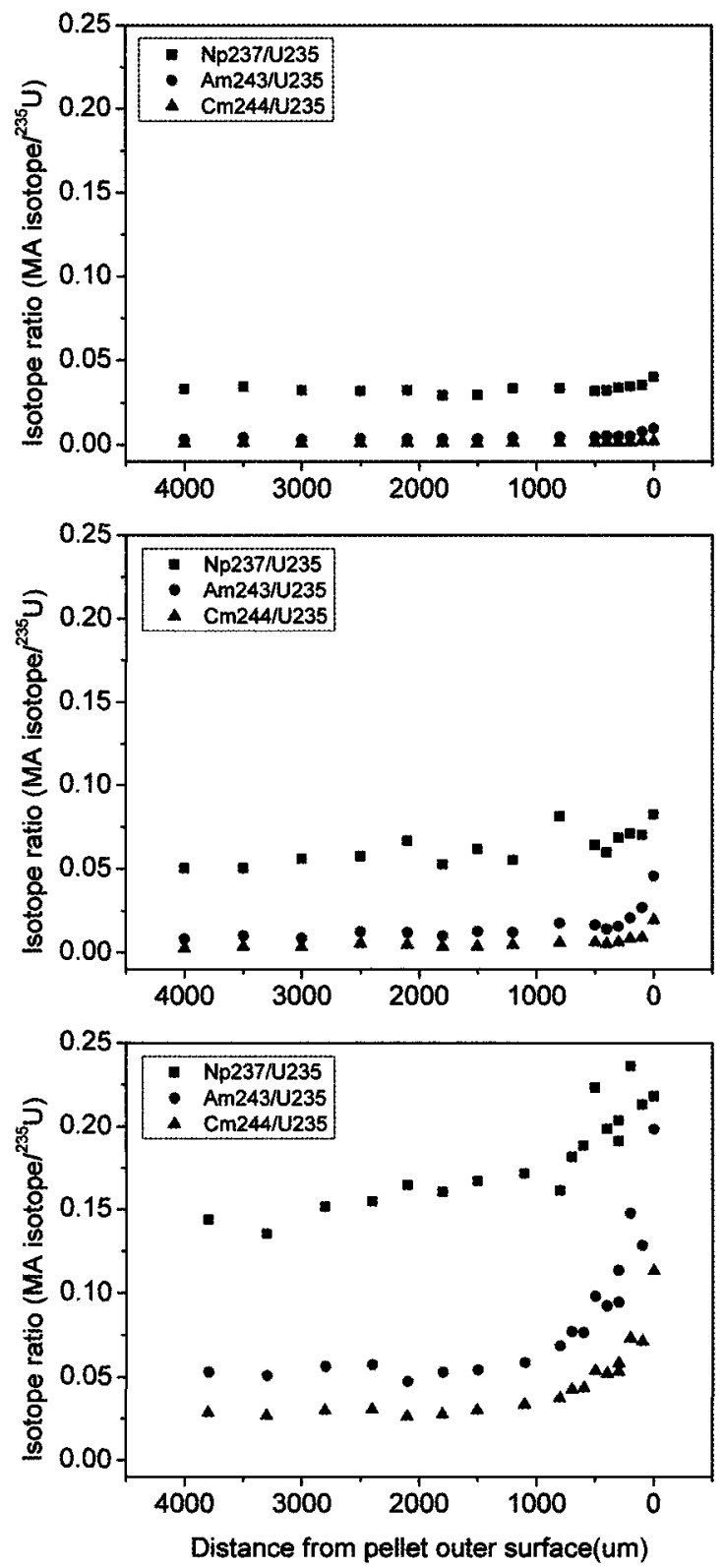

Fig. 6. Distributions of Minor Actinides $\left({ }^{237} \mathrm{~Np},{ }^{243} \mathrm{Am},{ }^{244} \mathrm{Cm}\right)$ across the Radius of Spent Nuclear Fuels Discharged from the Yeonggwang-2 PWR Reactor: (Top) $33.3 \mathrm{GWd} / \mathrm{tU}$, (Middle) 41.0 GWd/tU, (Bottom) $57.6 \mathrm{GWd} / \mathrm{tU}$

\subsection{Distribution of Minor Actinides (MAs) in the Spent Fuel Specimens}

The distributions of minor actinide isotopes were also studied. Among the several isotopes, ${ }^{237} \mathrm{~Np},{ }^{243} \mathrm{Am}$ and ${ }^{244} \mathrm{Cm}$ were chosen since the abundance of these isotopes are comparatively high and the interference by isobar is relatively low. The ${ }^{237} \mathrm{~Np}$ (half life, $\mathrm{t}_{1 / 2}=2.144 \times 10^{6}$ years) is produced by neutron capture and $\beta$ decay as follows $[15,16]$.

$$
\begin{aligned}
& { }^{235} \mathrm{U}(\mathrm{n}, \gamma)^{236} \mathrm{U}(\mathrm{n}, \gamma)^{237} \mathrm{U}^{\beta-} \rightarrow{ }^{237} \mathrm{~Np} \\
& { }^{238} \mathrm{U}(\mathrm{n}, \gamma) \stackrel{\beta-}{\beta-239} \mathrm{U} \stackrel{\beta-}{\rightarrow}{ }^{239} \mathrm{~Np} \stackrel{\beta-}{\rightarrow}{ }^{239} \mathrm{Pu}(\mathrm{n}, \gamma)^{240} \mathrm{Pu}(\mathrm{n}, \gamma)^{241} \mathrm{Pu} \rightarrow{ }^{241} \mathrm{Am} \rightarrow{ }^{237} \mathrm{~Np} \\
& { }^{238} \mathrm{U}(\mathrm{n}, 2 \mathrm{n})^{237} \mathrm{U}^{\beta-}{ }^{237} \mathrm{~Np}
\end{aligned}
$$

The most important isotopes of americium are ${ }^{241} \mathrm{Am}$ $\left(t_{1 / 2}=433\right.$ years $)$ and ${ }^{243} \mathrm{Am}\left(\mathrm{t}_{1 / 2}=7.38 \times 10^{3}\right.$ years $)$ due to the long half life. The ${ }^{243} \mathrm{Am}$ results from ${ }^{242} \mathrm{Pu}$ by neutron capture and $\beta$ decay as follows $[15,16]$.

$$
{ }^{242} \mathrm{Pu}(\mathrm{n}, \gamma)^{243} \mathrm{Pu} \stackrel{\boldsymbol{\beta}^{-}}{\rightarrow}{ }^{243} \mathrm{Am}
$$

The most common isotopes of curium are ${ }^{242} \mathrm{Cm}\left(\mathrm{t}_{1 / 2}\right.$ $=163$ days $)$ and ${ }^{244} \mathrm{Cm}\left(\mathrm{t}_{1 / 2}=18.1\right.$ years $)$. The largest quantity of curium exists as ${ }^{244} \mathrm{Cm}$, which is produced by successive neutron captures from ${ }^{239} \mathrm{Pu}$ to ${ }^{243} \mathrm{Pu}, \beta$ decay of ${ }^{243} \mathrm{Pu}$ and neutron capture by ${ }^{243} \mathrm{Am}$ as follows $[16,17]$.

$$
\begin{aligned}
& { }^{239} \mathrm{Pu}(\mathrm{n}, \gamma)^{240} \mathrm{Pu}(\mathrm{n}, \gamma)^{241} \mathrm{Pu}(\mathrm{n}, \gamma)^{242} \mathrm{Pu}(\mathrm{n}, \gamma)^{243} \mathrm{Pu} \\
& \stackrel{\beta-}{ }^{243} \mathrm{Am}(\mathrm{n}, \gamma)^{244} \mathrm{Am} \stackrel{{ }^{244} \mathrm{Cm}}{ }
\end{aligned}
$$

Fig. 6 shows the isotope ratios of ${ }^{237} \mathrm{~Np},{ }^{243} \mathrm{Am},{ }^{244} \mathrm{Cm}$ to ${ }^{235} \mathrm{U}$ as a function of the distance to the pellet rim. As can be observed, MA isotopes to ${ }^{235} \mathrm{U}$ ratios were increased at the pellet periphery and were an increasing trend as the burnup increases.

Fig. 7 shows the reproducibility of the isotope ratio determined by repeating measurements at the same position, and the relative standard deviations (RSDs) are listed in 
Table 5. Relative Standard Deviations (RSD, \%) of the Isotope Ratios of ${ }^{237} \mathrm{~Np},{ }^{243} \mathrm{Am},{ }^{244} \mathrm{Cm}$ to ${ }^{235} \mathrm{U}$ Measured at the Same Position in Spent Nuclear Fuels with Different Burnups

\begin{tabular}{c|c|c|c}
\hline \multirow{2}{*}{ isotope } & \multicolumn{3}{|c}{ RSD (\%) } \\
\cline { 2 - 4 } & $33.3 \mathrm{GWd} / \mathrm{tU}$ & $41.0 \mathrm{GWd} / \mathrm{tU}$ & $57.6 \mathrm{GWd} / \mathrm{tU}$ \\
\hline${ }^{237} \mathrm{~Np}$ & 16.97 & 3.93 & 5.59 \\
\hline${ }^{243} \mathrm{Am}$ & 18.82 & 7.05 & 6.35 \\
\hline${ }^{244} \mathrm{Cm}$ & 17.16 & 8.43 & 7.43 \\
\hline
\end{tabular}

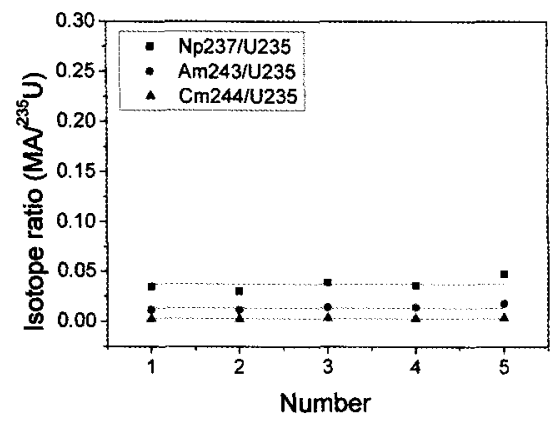

(a) P14P17-1

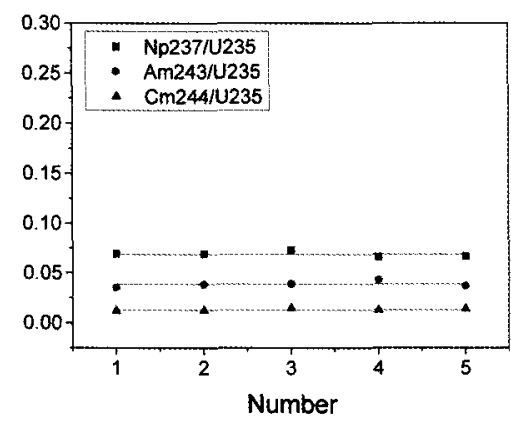

(b) P14P17-2

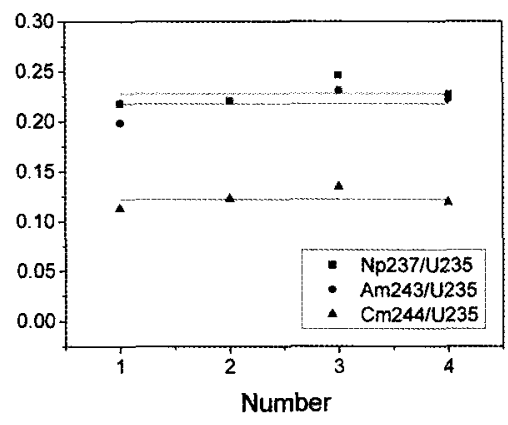

(c) P11Q01

Fig. 7. Reproducibility of Minor Actinides $\left({ }^{237} \mathrm{~Np},{ }^{243} \mathrm{Am},{ }^{244} \mathrm{Cm}\right)$ to ${ }^{235} \mathrm{U}$ Ratios Measured at the Same Position in Spent Fuel Specimens with Different Burnups: a) $33.3 \mathrm{GWd} / \mathrm{tU}$, b) $41.0 \mathrm{GWd} / \mathrm{tU}$, c) $57.6 \mathrm{GWd} / \mathrm{tU}$
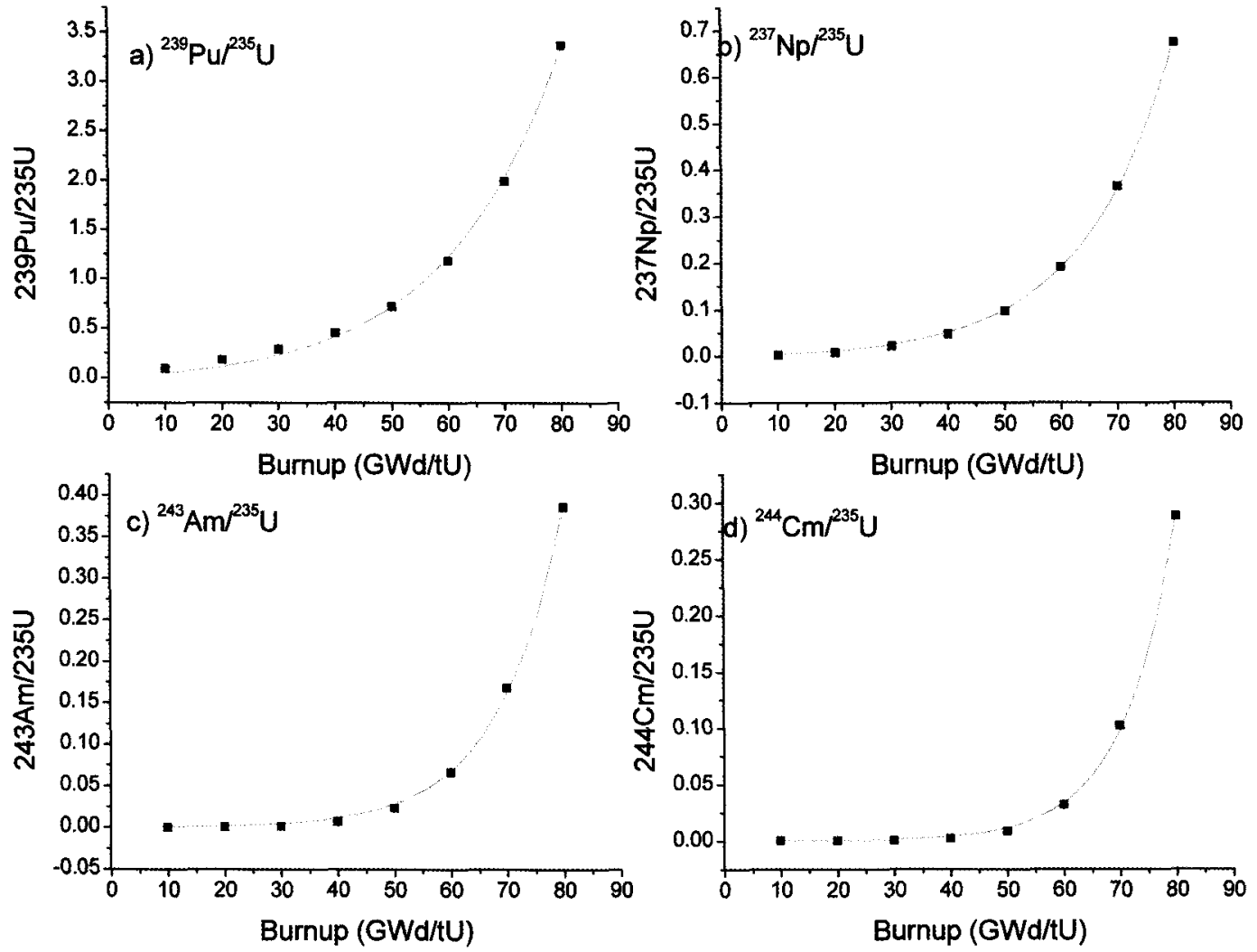

Fig. 8. Isotope Ratios Calculated by ORIGEN2 Code as a Function of Fuel Burnup 


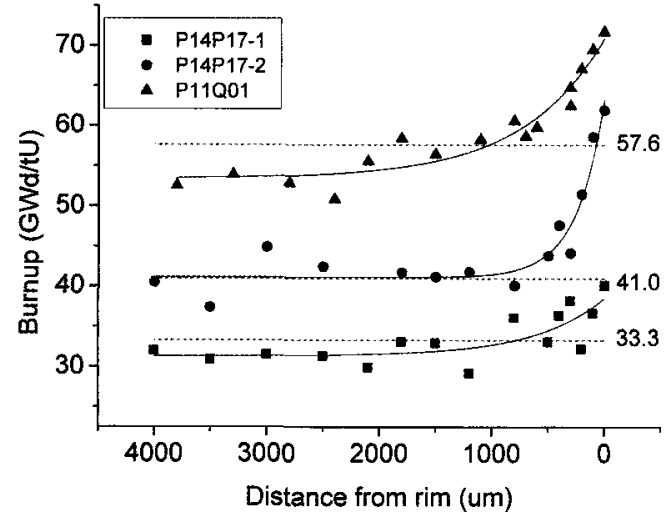

(a) ${ }^{239} \mathrm{Pu} /{ }^{235} \mathrm{U}$

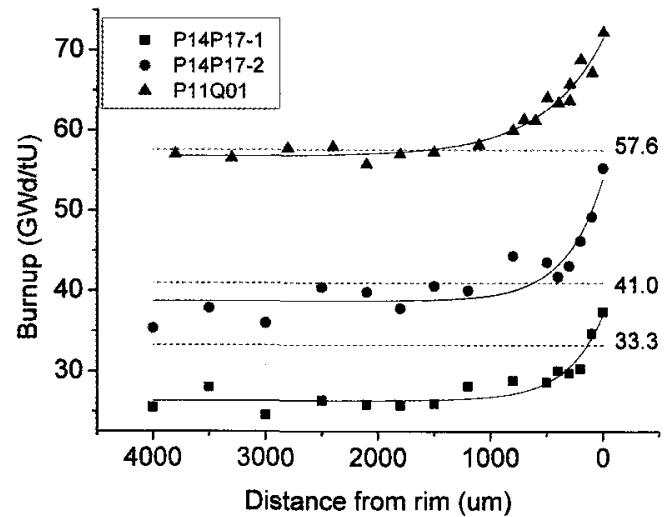

(c) ${ }^{243} \mathrm{Am} /{ }^{235} \mathrm{U}$

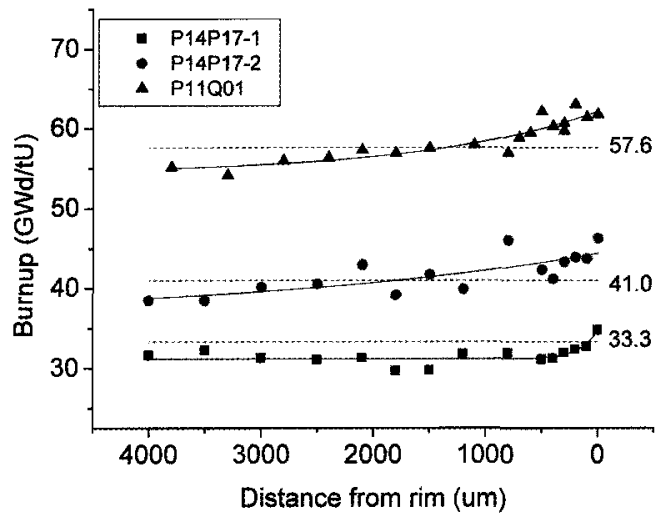

(b) ${ }^{237} \mathrm{~Np} /{ }^{235} \mathrm{U}$

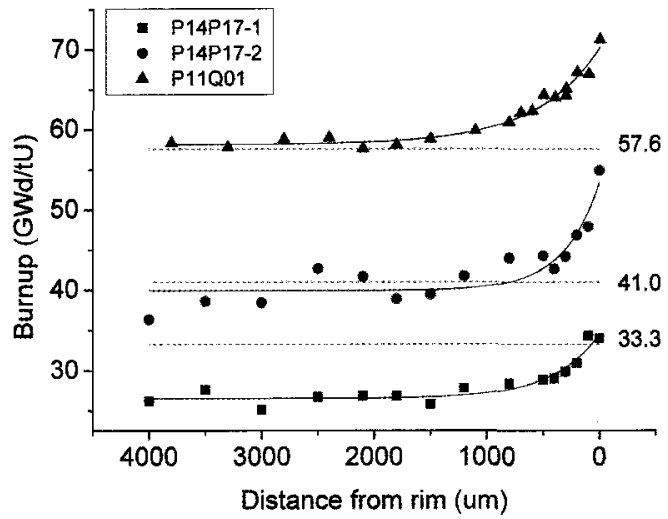

(d) ${ }^{244} \mathrm{Cm} /{ }^{235} \mathrm{U}$

Fig 9. Local Burnup Profiles of Spent Fuel Specimens. (Solid Line) Predicted Burnup Profiles Using the Measured (a) ${ }^{239} \mathrm{Pu} /{ }^{235} \mathrm{U}$, (b) ${ }^{237} \mathrm{~Np} /{ }^{235} \mathrm{U}$, (c) ${ }^{243} \mathrm{Am} /{ }^{235} \mathrm{U}$, (d) ${ }^{244} \mathrm{Cm} /{ }^{235} \mathrm{U}$ Ratio and ORIGEN2 Code. (Dashed Line) Average Specimen Burnup (P14P17-1: 33.3 GWd/tU, P14P17-2: 41.0 GWd/tU, P11Q01: 57.6 GWd/tU) Determined by Chemical Analysis (Nd-148 Method)

Table 5. Contrary to those for $\mathrm{U}$ and $\mathrm{Pu}$ isotopes, the measured RSD values of the MA isotopes were 17 to $19 \%$ for the lowest burnup and 6 to $7 \%$ for the highest burnup. It seems that low concentrations of MAs at low burnup resulted in higher deviation.

\subsection{Local Burnup Characteristics}

From the isotope ratio of measured actinides, local burnup was predicted. Fig. 8 shows the relationship between isotope ratios and burnups calculated by the ORIGEN2 code for a fuel with 3 years cooling after discharge and $4.5 \%$ enrichment. The isotopic ratios for ${ }^{239} \mathrm{Pu} /{ }^{235} \mathrm{U},{ }^{237} \mathrm{~Np} /{ }^{235} \mathrm{U}$, ${ }^{243} \mathrm{Am} /{ }^{235} \mathrm{U}$ and ${ }^{244} \mathrm{Cm} /{ }^{235} \mathrm{U}$ were increased exponentially as the burnup increases. The correlations can be expressed in the form

$$
y=A[\exp (x / t)-1]
$$

where $y$ is the isotopic ratio, $x$ is the burnup, and the values
Table 6. Values of $A, t$ and $y_{0}$ in Equation (2) for ${ }^{239} \mathrm{Pu} /{ }^{235} \mathrm{U}$, ${ }^{237} \mathrm{~Np} /{ }^{235} \mathrm{U},{ }^{243} \mathrm{Am} /{ }^{235} \mathrm{U}$ and ${ }^{244} \mathrm{Cm} /{ }^{235} \mathrm{U}$

\begin{tabular}{c|c|c}
\hline$y$ & $A$ & $t$ \\
\hline${ }^{239} \mathrm{Pu}{ }^{235} \mathrm{U}$ & 0.07025 & 20.5931 \\
\hline${ }^{237} \mathrm{~Np} /{ }^{235} \mathrm{U}$ & 0.00456 & 15.9744 \\
\hline${ }^{243} \mathrm{Am} /{ }^{235} \mathrm{U}$ & $3.79709 \times 10^{-4}$ & 11.5460 \\
\hline${ }^{244} \mathrm{Cm} /{ }^{235} \mathrm{U}$ & $5.50137 \times 10^{-5}$ & 9.3388 \\
\hline
\end{tabular}

of $A$ and $t$ for each isotopic ratio are summarized in Table 6.

From this correlation curve, the local burnups of the measured sample specimens were calculated as can be seen in Fig. 9. The solid lines in Fig. 9 show the radial local burnup profiles based on the correlation between the measured isotope ratios and the burnup predicted by the ORIGEN2 code. The dashed lines in Fig. 9 show the specimen average burnups determined by chemical analysis (Nd-148 method). It can be observed that the local burnup 
Table 7. Average Specimen Burnup Calculated by the Burnup Profile from the Measured Isotopic Ratios and ORIGEN2 Code

\begin{tabular}{c|c|c|c}
\hline Method & \multicolumn{3}{|c}{ Average specimen burnup (GWd/tU) } \\
\hline${ }^{239} \mathrm{Pu} /{ }^{235} \mathrm{U}$ distribution & 32.4 & 42.6 & 56.8 \\
\hline${ }^{237} \mathrm{~Np} /{ }^{235} \mathrm{U}$ distribution & 31.3 & 41.0 & 57.3 \\
\hline${ }^{243} \mathrm{Am} /{ }^{235} \mathrm{U}$ distribution & 27.3 & 40.1 & 58.9 \\
\hline${ }^{244} \mathrm{Cm} /{ }^{235} \mathrm{U}$ distribution & 27.4 & 41.1 & 60.0 \\
\hline $\mathrm{Nd}-148$ method & 33.3 & 41.0 & 57.6 \\
\hline
\end{tabular}

increases at the pellet periphery regardless of specimen burnup, but the rate of increase in the periphery region changes as burnup increases. The burnup profiles predicted by the ${ }^{239} \mathrm{Pu} /{ }^{235} \mathrm{U},{ }^{243} \mathrm{Am} /{ }^{235} \mathrm{U}$ and ${ }^{244} \mathrm{Cm} /{ }^{235} \mathrm{U}$ ratios agreed comparatively well with each other, while the ${ }^{237} \mathrm{~Np} /{ }^{235} \mathrm{U}$ ratio gives lower local burnups at the pellet periphery. Table 7 lists the average specimen burnups predicted by different methods. The specimen average burnups estimated by solid lines in Fig. 9 are 29.6 $2.6,41.2 \pm 1.0$, and $58.2 \pm 1.5$ GWd/tU for P14P17-1, P14P17-2, and P11Q01, respectively. These values agreed considerably well with that of the Nd-148 method, though the specimen of lower burnup deviates to some extent to the lower value. This therefore suggests that the burnup profiles obtained by local isotopic ratios can be useful burnup monitors.

\section{CONCLUSIONS}

Local burnup radial profiles were evaluated from the radial distributions of actinide isotopes in spent nuclear fuel. The radiation shielded LA-ICP-MS was employed to measure the isotope distributions of $\mathrm{U}, \mathrm{Pu}$ and other actinides in the spent nuclear fuels discharged from the Yeonggwang-2 NPP in Korea. It was observed that the isotope ratio of ${ }^{236} \mathrm{U}$ to ${ }^{235} \mathrm{U}$ is almost constant from the center to the periphery of the fuel pellet and that of $\mathrm{Pu}$ increased significantly near the pellet periphery due to the epi-thermal neutron capture by ${ }^{238} \mathrm{U}$ (so-called rim effect). Changes in the isotope distributions of $\mathrm{Pu}$ and other actinides in spent fuel specimens with three different burnups were measured. The obtained data provides an estimate of the local burnup profiles by comparison with calculated values, suggesting the potential to become a useful burnup monitor. The results are useful for a better understanding of the irradiation behaviors of highly burnt spent nuclear fuel. Further experimental studies are underway in order to determine the distribution of fission products forming metallic precipitates, an insoluble oxide or volatile element in spent fuel.

\section{ACKNOWLEDGMENTS}

This work was supported by the Nuclear Research \& Development Program of the Korea Science and
Engineering Foundation (KOSEF) grant funded by the Korean government (MEST). (Grant Code: M2070301000308M0301-00310)

\section{REFERENCES}

[1] W. J. Lee, Y. W. Kim and J. Chang, "Perspectives of Nuclear Heat and Hydrogen", Nuclear Engineering and Technology, Vol. 41(4), p.413 (2009)

[2] Hj. Matzke, M. Coquerelle, K. Lassmann, I.L.F. Ray, C. Ronchi and C.T. Walker, "Oxide Fuel Transients", Journal of Nuclear Materials, Vol. 166, p. 165 (1989)

[3] Hj. Matzke, "On the Rim Effect in the High Burnup $\mathrm{UO}_{2}$ LWR Fuels", Journal of Nuclear Materials, Vol. 189, p.141 (1992)

[4] J.I. Garcia Alonso, D. Thoby-Schultzzendorff, B. Giovanonne, J.-P. Glatz, G. Pagliosa, L. Koch, "Characterization of Spent Nuclear Fuel Dissolver Solutions and Dissolution Residues by Inductively Coupled Plasma Mass Spectrometry", Journal of Analytical Atomic Spectrometry, Vol. 9, p.1209 (1994)

[ 5 ] J.S. Becker, "Mass Spectrometry of Long-lived Radionuclides", Spectrochimica Acta, Part B, Vol. 58, p.1757 (2003)

[6] J.S. Kim, S.H. Han, M.Y. Suh, J.S. Joe and T.Y. Eom, "Burnup Measurement of Irradiated Uranium Dioxide Fuel by Chemical Methods", Journal of Korean Nuclear Society, Vol. 21(4), p.277 (1989)

[ 7 ] E.R. Denoyer and K. J. Fredeen, "Laser Solid Sampling for Inductively Coupled Plasma Mass Spectrometry", Analytical Chemistry, Vol. 63, No.8, 445 (1991)

[8 ] C. Pickhardt, J.S. Becker and H.-J. Dietze, "A New Strategy of Solution Calibration in Laser Ablation Inductively Coupled Plasma Mass Spectrometry for Multielement Trace Analysis of Geological Samples", Fresenius Journal of Analytical Chemistry, Vol. 368, p.173 (2000)

[9] Y-K. Ha, S.H. Hahn, H.G Kim, W.H. Kim and K.Y. Jee, "Shielded Laser Ablation ICP-MS System for the Characterization of High Burnup Fuel," Nuclear Engineering and Technology, Vol. 40(4), p.311 (2008).

[10] J.S. Becker, "Inductively Coupled Plasma Mass Spectrometry (ICP-MS) and Laser Ablation ICP-MS for Isotope Analysis of Long-lived Radionuclides," International Journal of Mass Spectrometry, Vol. 242, p.183 (2005)

[11] "Atom Percent Fission in Uranium and Plutonium Fuel (Neodymium-148 Method)," American Society for Testing and Materials Standard Method E321-96, 1 (1996)

[12] J.S. Kim, Y.S. Jeon, S.D. Park, B.C. Song, S.H. Han, and J.G. Kim, "Dissolution and Burnup Determination of 
Irradiated U-Zr Alloy Nuclear Fuel by Chemical Methods", Nuclear Engineering and Technology, Vol. 38(3), p.301 (2006)

[13] P. D. Regge and R. Boden, "Determination of Neodymium Isotopes as Burnup Indicator of Highly Irradiated (U,Pu)O2 LMFBR FUEL", Journal of Radioanalytical Chemistry, Vol. 35, p.173 (1977)

[14] J.I. Garcia Alonso, J. Garcia Serrano, J.F. Babelot, J.-C. Closset, G. Nicolaou, and L. Koch, "Laser Ablation ICPMS on Spent Nuclear Fuel", Application of Plasma Source Mass Spectrometry II, RSC, special publication No.124, p.
193 (1993)

[15] H. Werner, "Build-up of Plutonium Isotopes in HTR Fuel Elements: A Comparison Between Computed Prediction and Chemical Analysis", Nuclear Engineering and Design, Vol. 170, p. 147 (1997)

[16] Lester R. Morss, Norman M. Edelstein and Jean Fuger, The Chemistry of the Actinide and Transactinide Elements, $3^{\text {rd }}$ ed. Springer (2006)

[17] C. Madic, J. Bourges, and G. Koehly, "Preparation of Nuclide and Sources of Actinides Elements", Nuclear Instruments and Methods in Physics Research, A236, p. 474 (1985) 